\title{
The Issue of Gender Equity in Computer Science - What Students Say
}

\author{
Iwona Miliszewska, Gayle Barker, \\ Fiona Henderson, and Ewa Sztendur \\ Victoria University, Melbourne, Australia
}

\author{
Iwona.Miliszewska@vu.edu.au Gayle.Barker@vu.edu.au \\ Fiona.Henderson@vu.edu.au ewa@csm.vu.edu.au

\section{Executive Summary}

The under-representation and poor retention of women in computing courses at Victoria University is a concern that has continued to defy all attempts to resolve it. Despite a range of initiatives created to encourage participation and improve retention of females in the courses, the percentage of female enrolments has declined significantly in recent years, from 32\% in 1994 to $18 \%$ in 2004 , while attrition rates soared to $40 \%$ in 2003 . A recent research study investigated these negative trends with respect to gender equity in computing courses: of interest was the possibility of gender bias in the learning environment and its impact on female attrition rates. Focus groups and surveys involving computing students of both genders were used as data collection tools in the study.

The overall findings from the focus groups were rather surprising, as they yielded no strong indication of gender bias in the learning environment of the computing course; this applied to the logistical arrangements, academic staff, pedagogical methods, and course content. The thesis that the existence of gender bias in the learning environment contributes to high attrition rates of females in computing courses was not sufficiently supported. While the fact that students, both male and female, found their learning environment gender neutral was comforting, the realization that reasons other than gender bias drove females away from the computing course was not. High attrition rate of females remains the reality. Possible explanations of this phenomenon were suggested by the focus groups, and the search for confirmation of these indications and discovery of other contributing factors continued.

The results of a subsequent survey confirmed several of the focus groups findings: the lack of gender balance in the course was considered immaterial, as was the gender of the lecturers and tutors; the course curriculum was deemed gender neutral; and, overall difficulty of the course and overall satisfaction with the course were rated similarly by both male and female students. Some of the survey results contradicted findings of the focus groups, notably the reported equal access

Material published as part of this journal, either on-line or in print, is copyrighted by the Informing Science Institute. Permission to make digital or paper copy of part or all of these works for personal or classroom use is granted without fee provided that the copies are not made or distributed for profit or commercial advantage AND that copies 1) bear this notice in full and 2) give the full citation on the first page. It is permissible to abstract these works so long as credit is given. To copy in all other cases or to republish or to post on a server or to redistribute to lists requires specific permission and payment of a fee. Contact Publisher@InformingScience.org to request redistribution permission. to computers in laboratories and groupwork unaffected by the gender of group members. Moreover, although female students did not regard the underrepresentation of females in the course as a problem, they singled out their fellow female students as the vital source of both academic and personal help, thereby reiterating the need for female peers in the course. 
The first year, particularly the first semester, of the course emerged as the 'make or break' period especially for female students. Not only was it an important period with respect to adjustment to the course but also it was a period most likely to influence most female students' decisions about quitting the course. It appears that staff encouragement mattered little in dissuading female students from quitting, but the support of fellow students was important.

Transition into the course, rather than gender bias, was identified as a possible factor contributing to high attrition rates of females in computing courses. Not only did the female students take considerably longer to settle into the course - up to six months, but they also were most likely to drop out of the course after the first year of study. This is of concern for two reasons: firstly, because of the large number of students contemplating dropping out; and secondly, because the role of the academic staff in persuading those students to stay was regarded as largely insignificant by the students.

This study provides some explanation of the high attrition of females in computing courses, but the challenge still remains to develop effective strategies to halt this negative trend.

Keywords: gender bias, computing education, female participation, female under-representation, learning environment, retention.

\section{Introduction}

The participation of women in science and, more recently, in information and communications technology (ICT) has engaged researchers for more than twenty years. Despite extensive research and numerous practical interventions designed to address the relative dearth of women in ICT, the problem persists. Evidence from around the world suggests that despite female predominance in undergraduate enrolments (59\% in Australia, 55\% in America, and greater than 50\% in many European Union countries), women are reluctant to pursue ICT study at tertiary level (Rees, 2001). In addition, research literature indicates that irrespective of discipline, the proportion of female undergraduates in the discipline, and country, women leave scientific careers in disproportionate numbers at every stage (Henwood \& Miller, 2001, p. 239). For ICT, which already starts with a disproportionately small number of first-year female students, this trend is particularly disturbing.

Initial approaches to address the under-representation of women in ICT at tertiary level centered upon notions of equality and affirmative action. Since ICT has always been perceived as incorporating access to powerful forms of knowledge and providing highly remunerative employment opportunities, the lack of significant numbers of females in the discipline was seen as inequitable. To alleviate the problem, a number of intervention programs aimed at women have promoted information on technology-related careers, provided experience of computing work and have highlighted female role models. Other programs focused on helping women develop skills, attitudes or background knowledge that women were thought to lack. However, the goal of these programs was to produce equality - or sameness - between women and men, and thus focused on changing women in ways that would make them more like men (Gilbert, 2001). A basic flaw in this drive for equality of outcome was assuming the male as the norm. Similarly, the affirmative action measures, while commendable and essential in fostering gender equality, were not sufficient. Indeed, in many programs these actions only served to reinforce the conceptions of ICT as a masculine domain - they were aimed at encouraging women to participate in a male-dominated culture, rather than challenging the notions of it.

Despite many such initiatives worldwide, women continue to be underrepresented in the ICT discipline. This suggests that an alternative approach and a shift of focus is needed. Rather than encouraging women to act like men, ICT needs to be reconceptualized into an environment that women would naturally embrace. A first step in this reconceptualization is to understand the ways 
in which perceptions of the technology, in terms of its societal realization and its educational programs, affect the choices women make. A subsequent step would be to effect a female-friendly adjustment to all areas of ICT including education. An important aspect of this two-step approach involves the systematic collection, analysis and publication of relevant gender-disaggregated statistics. Such a task, in the area of tertiary computing education, motivated this project: its investigative stage is reported in this paper.

The aim of the project was to develop and evaluate strategies to improve progression and retention rates of female students enrolled in computer science courses at Victoria University. The approach was to firstly investigate the perceived problems from the students' perspective the study was to focus on problems related to the learning environment, particularly on direct and subtle gender-related problems encountered in the classroom, and special needs of female students. Secondly, based on the collected information, an integrated strategy targeting the female students was to be developed; and lastly, the strategy was to be implemented and evaluated.

\section{Gender-related issues in ICT education}

The under-representation and poor retention of female students in ICT courses, including computer science, both in Australia and overseas, has been well recognized. The already low number of female students enrolling in computer science is usually further decimated by high attrition rates. Although Scragg and Smith (1998) point to ineffective recruitment as the main cause of low female participation, the diminishing numbers caused by female attrition remain a concern. This situation has often been attributed to gender differences in interests, motivation, experience, personality characteristics, abilities, self-efficacy and socialization. These differences, which put females at a disadvantage in computing courses, stem from a variety of factors both external and internal to the institution offering the course. External factors include the popular perception of the male dominated computing culture, its particularly masculine character and, often, a 'geek' image. The internal factors include environmental aspects such as inadequate pedagogical techniques, stereotypical attitudes of lecturers, tutors and fellow students, as well as lack of role models and proper institutional support (Fisher, 2003; Margolis, Fisher \& Miller, 1998; Miliszewska \& Horwood, 2002; Newmarch, Taylor-Steele \& Cumston 2000; Nielsen, von Hellens \& Wong, 2001).

While external factors generate female students' sense of isolation in the course, as well as low self-confidence in their computing skills, abilities and accomplishments even prior to entering the course (Lazowska, 2002; Zeldin \& Pajares, 2000), internal factors are likely to deepen existing negative impressions even further, and create new ones through:

- Negative classroom experiences - caused by assumptions of prior knowledge and hands-on experience with computers, stereotypical attitudes and interaction style (often patronising or aggressive) of lecturers, tutors and fellow students (Lazowska, 2002; Scragg \& Smith, 1998); lack of structured environment and detailed instructions (Crump, 2001); as well as unwanted positive discrimination (Nielsen et al., 2001);

- Inadequate access to computers in the classroom - often dependent on the level of aggressiveness of fellow students (Clayton \& Lynch, 2002; Davies, Klawe, Ng, Nyhus \& Sullivan, 2000);

- Unequal participation in class - females are not allocated equal time on computers, are not called on equally in class, are not assigned equally difficult tasks, are not part of the interaction between lecturer and students as often as males (Levenson, 1999);

- Lack of interesting gender-neutral projects in the course - the course includes few goaloriented tasks that relate well to the real-world, and on which females could work in teams 
(Weinman \& Haag, 1999); lack of problems and examples from diverse disciplines outside of computer science (Blank \& Kumar, 2002; Cohoon, 2002; Margolis, Fisher \& Miller, 1999);

- Lack of role models and career advice - few female lecturers and tutors, few female fellow students, 'invisible' successful career women, stereotypical career impressions and a lack of information about computing as a career (Camp, 1997; Cohoon, 2001; Crombie, Abarbanel \& Anderson, 2001; Teague, 2002);

- Inadequate institutional support - lack of special programs that would enable females to learn computer jargon and help them feel comfortable around computers; lack of encouragement and mentoring on the part of the lecturers; lack of institutional support in gender-sensitive teaching (Cohoon, 2001; Crump, 2001);

- Lack of peer support groups - lack of interaction between, and lack of support networks among, students in class (Springer, Stanne \& Donovan, 1999).

Despite the existing body of research, there is no consensus on the gender disparity in computer science. Research results are varied and conflicting (Haliburton, Thweatt \& Wahl, 1998) and, while the reasons why females desert computer science are still unclear, female representation in the discipline continues to decline.

\section{Gender and ICT at Victoria University}

Participation and retention of females in computer science at Victoria University is a particularly elusive issue. Computer science appears, on the surface, to offer one of the more attractive scenarios to potential female students - gender-neutral curriculum, attractive career path and high salary scale. The success of past female graduates proves that females can and have succeeded in this area. Why then are the trends in the opposite direction? This is an important question since computing and computer competence are critical to ongoing developments of the 'information revolution'.

A study conducted in the School of Computer Science and Mathematics in 1999 investigated factors that influence women's entry into computer science, their journey through their studies and issues that engage women on their way to becoming computer scientists (Miliszewska \& Horwood, 2000). The study identified two external factors of career stereotyping and misperceptions about the nature of computing as the main factors deterring females from studying computer science. Over the past decade, the School engaged in a range of initiatives to counter these factors, encourage participation and improve retention of females in computer science. Those initiatives, focusing on the environment outside the classroom, included University Open Days, career nights, school visits, computing workshops and a Science Week for Year 9 and 10 secondary school students. Despite the efforts, the percentage of female enrolments in computer science has declined considerably in the past ten years (Table 1).

Table 1: Participation by females in computer science at Victoria University

(as percentage of total number of students in computer science)

\begin{tabular}{|c|c|c|c|c|c|c|c|c|c|c|}
\hline 1994 & 1995 & 1996 & 1997 & 1998 & 1999 & 2000 & 2001 & 2002 & 2003 & 2004 \\
\hline 31 & 32 & 28 & 20.6 & 18.1 & 18.6 & 20.1 & 20 & 19.3 & 18.5 & 18.2 \\
\hline
\end{tabular}

The 30\% participation rate of 1994-96 represented a willingness by women to study computer science. By contrast, the situation at Victoria University in recent years has been particularly disturbing, especially when compared with the current national average of $26 \%$, and the national 
objective of $40 \%$. While the participation rates have declined steadily over the past decade, the attrition rates of females have remained consistently high across all year levels, with the biggest attrition rates recorded for females in their first year of studies. A particularly sharp increase is evidenced for the cohorts commencing in 2002 and 2003 (Table 2).

Table 2: Attrition of students after first year at Victoria University

(as percentage of students commencing in a given year)

\begin{tabular}{|l|c|c|c|c|c|c|c|}
\hline Year & 1997 & 1998 & 1999 & 2000 & 2001 & 2002 & 2003 \\
\hline $\begin{array}{l}\text { Females in } \\
\text { computer science }\end{array}$ & 34 & 30 & 33 & 18 & 23 & 32 & 40 \\
\hline $\begin{array}{l}\text { Males in } \\
\text { computer science }\end{array}$ & - & - & - & - & 24 & 25 & 29 \\
\hline $\begin{array}{l}\text { All students at } \\
\text { Victoria University }\end{array}$ & 24 & 26 & 28 & 28 & - & 24 & 25 \\
\hline
\end{tabular}

"_." indicates that data is not available

The attrition data for females in computing shown in Table 2 was painstakingly obtained by a research assistant who manually ploughed through individual female student records; this process took considerable time and effort and could not be replicated for the even larger number of male computing students. The University student record system was undergoing an overhaul at that time; its new version can now provide statistics for males, but only dating back to 2001 . Rates for commencing bachelor students in all majors at Victoria University are provided for comparison (DEST, 2004, 2005).

Since various initiatives undertaken by the School after the 1999 study failed to impact long-term on these disappointing trends, it appeared that the underlying problems resided elsewhere and that new research was needed to guide retention efforts. The challenge was to locate those problems and implement suitable responses. It was decided to conduct a study that, unlike the previous study, would focus on internal factors, particularly the classroom environment. The objective was to investigate issues pertinent to the pedagogy and content of computer science courses, as well as the classroom climate, with a goal to make the discipline more inclusive for female students.

\section{The Research Study}

The main aims of the research study were threefold: firstly to identify the types of problems faced by female students in the classroom environment, and uncover any special needs of female students; secondly, to develop a practical strategy to promote equity for females in computer science; and thirdly, to implement the strategy.

To realize the aims of the study in the most balanced and considerate manner and taking into account a socially and ethnically diverse student population, a multidisciplinary research team was formed in mid 2003. The investigators included academics not only from the School of Computer Science and Mathematics, but also the School of Communications, Culture and Languages and the Student Learning Unit, since the computing students undertake a number of communications subjects in their course. A representative from the university's Equity and Social Justice Branch also joined the research team. Funding for the study was secured from the government-sponsored Higher Education Equity Program (HEEP); the School of Computer Science and Mathematics also made a contribution. 
The investigative phase of the study involved gathering information about problems faced by female students in the classroom environment, and determining any special needs of female students. The task was not only to identify the problems but also to establish if they stemmed from the internal factors reported in research literature as contributors to female attrition rates. It was important to establish if those factors including negative classroom experiences, inadequate access to computers in the classroom, unequal participation in the class, lack of gender-neutral course materials, lack of role models and career advice, lack of peer support groups, and inadequate institutional support were applicable to female computing students at Victoria University. It was also important to seek the views of both female and male students on the above factors to determine if the participants' views varied depending on their gender. Focus groups and a survey were used for data collection. It was decided that feedback from focus groups needed to be collected prior to the survey to enable a better, non-prescriptive survey design.

\section{Focus Groups Findings}

Four focus groups consisting of two single gender groups and two mixed gender groups were conducted: thirty-two students representing both genders and all year levels participated. The central topic of the focus groups was gender equity in the computing learning environment; the key question - 'Why do female students drop out of the course?' The comments made by students during focus groups centered around issues of gender balance of both students and teachers, course content, resource access and collaborative activities.

\section{Gender Balance}

The fact that the majority of students in the computing course were male was of little concern to either male or female students. Similarly, students did not regard the gender of the lecturers as a crucial issue in their learning. The importance was not gender but competence and good teaching skills. However, female students perceived female lecturers as more friendly and approachable. There was clear evidence in the comments made by all students that there was a need to bond with their lecturers in a social way.

\section{Course Content and Resource Access}

Attitudes to the content of the course were more ambivalent. Although all students felt that the course content was determined by its technical nature, there was some acknowledgment that more alternative 'female-friendly' practical course material might have been chosen. On the other hand, both female and male students considered that they had equal access to computers in the computer laboratories and that there was no evidence of male dominance or 'bullying' in claiming available machines. The suggestion, reported in research literature, that male students tend to 'hog' computers and exclude female students was met by all students with utter disbelief.

\section{Collaborative Activities}

With respect to group work, the only interest that potential group members had in each other was their competence and willingness to work; gender seemed immaterial. Interestingly, all students testified to a truly collaborative approach to group work with the work being shared and rotated within the group to ensure that all members, female and male, gained experience of the differing demands of the project. The recognition of the skills that each member brought to a group project was clearly evident. 


\section{Further Reasons for High Attrition of Females}

When asked for the reasons for female students dropping out, responses were more guarded. However, lack of self-confidence and lack of friendships were considered major factors, as was the overall difficulty of the course, particularly programming subjects; lack of interest in the course from the beginning and family concerns were also perceived as a contributing factor. Female students expressed the need for more support, especially of a social nature. They perceived a need for students to be better prepared for the university experience and also showed sympathy for those students who chose to leave the course; further, they hoped the incidence of female attrition in future years might be arrested.

\section{Summary}

The overall findings from the focus groups were rather surprising, as they yielded no strong indication of gender bias in the learning environment of the computing course. The focus group moderator emerged from the focus group sessions somewhat baffled having expected answers that would support the original hypothesis of the research study - that the existence of gender bias in the learning environment contributes to high attrition rates of females in computing courses. That thesis was not sufficiently supported. The focus group moderator concluded the students are telling me that there is no entrenched overall problem: you are doing a good job!

It was a bitter/sweet conclusion: sweet was the knowledge that the students, both male and female, found their learning environment gender neutral; bitter was the realization that if gender bias did not drive females away from the computing course, then something else did. High attrition rate of females remains the reality. Possible explanations of this phenomenon have been suggested by the focus groups, and the search for confirmation of these clues and discovery of other contributing factors continued.

\section{Survey Results}

Following the analysis of focus group findings, a survey was developed to seek confirmation of these findings from a wider cohort of computing students and discover other factors contributing to growing female attrition rates. Two hundred and ten students from the undergraduate computing course completed the survey: 47 female, and 163 male students. The respondents were young, the median age for females was 23, and for males 21 years. They came from a spread of all year levels of the course, so the collected data was not biased by new students who may have been inexperienced in their judgments. They typified the students in the course, and indeed the University, with respect to their ethnic origin and educational background. Almost $68 \%$ of students were born overseas, one quarter of which were born in Vietnam. Nearly $56 \%$ of all respondents spoke only a language other than English at home. There was a significant difference between the genders with respect to educational background (Pearson Chi-Square test, $\mathrm{p}=0.023$ ), $65 \%$ of male students entered the course straight after high school, as opposed to $49 \%$ of females. Although the majority of students entered the computing course directly after completing high school, $28 \%$ of males and $38 \%$ of females entered the course after completing other types of further training.

\section{Transition to the Course}

Students indicated the importance of reasons for selecting the computing course at Victoria University. Location, reputation, and other students were listed as possible reasons. Students, both male and female, selected location as the most important reason for choosing the course (Wilcoxon test, $\mathrm{p}<0.001$ (females), $\mathrm{p}=0.003$ (males)). Although $64 \%$ of females regarded location as important or very important, as opposed to $47 \%$ of males, the difference between genders was not statistically significant. 
Students also indicated the level of difficulty adjusting to the course and university life, as well as balancing studies with other commitments. Although a greater percentage of female students found coping with study load, finding friends, and balancing study with family and work commitments difficult, the differences were not significant in comparison with male students. Likewise, although $29 \%$ of females as opposed to $37 \%$ of males ranked overall level of difficulty as 'difficult' or 'very difficult', the difference in proportions was not significant. A summary of the findings is presented in Table 3.

\section{Table 3: Percentage of students who found adjustment to university studies difficult}

\begin{tabular}{|l|c|c|}
\hline Aspect of studies & Females & Males \\
\hline Coping with study load & 34 & 26 \\
\hline Finding friends & 24 & 16 \\
\hline Finding help & 24 & 26 \\
\hline Securing financial support & 33 & 35 \\
\hline Balancing study with family commitments & 43 & 36 \\
\hline Balancing study with work commitments & 47 & 39 \\
\hline Overall level of difficulty & 29 & 37 \\
\hline
\end{tabular}

Another important transition issue was that of adjustment duration. A majority of all students ( $78 \%$ of females and $84 \%$ of males) settled into the course within the first six months. However, male students adjusted much more quickly; nearly $60 \%$ of male students took less than two months to settle, as opposed to $38 \%$ of females in the same time period - the difference is significant (Pearson Chi-Square test, $\mathrm{p}=0.096, \alpha=0.1$ ). A summary of the findings is presented in Table 4.

Table 4: Percentage of students in a given settlement period

\begin{tabular}{|l|c|c|}
\hline Settlement period & Females & Males \\
\hline Less than one month & 29 & 34 \\
\hline Less than two months & 9 & 25 \\
\hline About six months & 40 & 25 \\
\hline About one year & 13 & 10 \\
\hline More than one year & 9 & 6 \\
\hline
\end{tabular}

\section{Satisfaction with the Course}

Student satisfaction with various aspects of the course was also examined. The level of satisfaction/dissatisfaction with several aspects of the course was the same for both genders. However, there were differences with satisfaction with course content. Views were more polarized among female students. A greater percentage of females than males found it satisfactory ( $43 \%$ versus $31 \%$ ) but at the same time, more females than males found it unsatisfactory $(21 \%$ versus $15 \%)$; the difference was not significant. Female students were more satisfied, but not significantly, with 
the lecturers'/tutors' availability to help. Significant difference between the genders occurred only with satisfaction about own performance; male students were more satisfied with own performance than their female counterparts (Pearson Chi-Square test, $\mathrm{p}=0.001$ ). A summary of results is presented in Table 5.

Table 5: Satisfaction with the course (as percentage of students) (4,5 - satisfied, very satisfied; 1,2 - very dissatisfied, dissatisfied)

\begin{tabular}{|l|c|c|c|c|}
\hline & \multicolumn{2}{|c|}{ Females } & \multicolumn{2}{c|}{ Males } \\
\hline Aspect of the course & $\mathbf{( 4 , 5 )}$ & $\mathbf{( 1 , 2 )}$ & $\mathbf{( 4 , 5 )}$ & $\mathbf{( 1 , 2 )}$ \\
\hline Choice of course & 53 & 13 & 57 & 11 \\
\hline Course content & 43 & 21 & 31 & 15 \\
\hline Assessment & 44 & 7 & 39 & 8 \\
\hline Lecturers'/Tutors' teaching ability & 33 & 27 & 39 & 25 \\
\hline Lecturers'/Tutors' availability to help & 53 & 15 & 40 & 26 \\
\hline Fellow students/friends & 68 & 6 & 67 & 7 \\
\hline Own performance & 44 & 7 & 55 & 10 \\
\hline Overall level of satisfaction & 45 & 9 & 48 & 8 \\
\hline
\end{tabular}

Students' intentions to quit the course were also examined. While one half of the students $(53 \%$ of females and $48 \%$ of males) never considered quitting, the other half thought about it $-17 \%$ of both females and males alike thought about it seriously. Students indicated the importance of various factors that influenced their decision to continue in the course. While the encouragement of fellow students played a greater role with female than male students, the difference was not significant. The only significant difference was noted with respect to the importance of family encouragement; it had a significantly greater bearing on male students' decisions to continue with the course (Pearson Chi-Square test, $\mathrm{p}=0.012$ ). A summary of the findings is presented in Table 6 .

\section{Table 6: Factors influencing decision to stay in the course (as percentage of students)}

\begin{tabular}{|l|c|c|}
\hline Factor & Females & Males \\
\hline Family encouragement & 32 & 45 \\
\hline Staff encouragement & 19 & 11 \\
\hline Fellow student encouragement & 46 & 28 \\
\hline Resolution of the problem & 29 & 25 \\
\hline Self-determination to continue & 33 & 45 \\
\hline
\end{tabular}

No correlation was found between the students' intentions to quit the course and either their educational or ethnic backgrounds. However, a comparison between the intention to quit and the students' current year of study revealed that the intention was strongest among females in their second year of study - nearly $60 \%$ of them considered quitting. 


\section{The Issue of Gender in the Course}

Students expressed their views on various aspects of the course related to possible gender bias, for example access to computers, quality of course material (with respect to gender bias), willingness to speak in class, and others. More than half of the students of either gender did not regard the under-representation of females in the course as a problem; interestingly fewer females than males $(17 \%$ versus $28 \%)$ felt that under-representation of females in the course was a problem. However, female students tended to agree more that male students 'hogged' computers in laboratories (Mann-Whitney test, $\mathrm{p}=0.032$ ). Female students preferred not to work with other students, particularly male, and the difference in preferences in comparison to their male counterparts was significant (Mann-Whitney test, $\mathrm{p}<0.001$ ).

The content of the curriculum was considered largely gender neutral by both genders, and the distribution of agreement was similar for both groups. Both groups were equally comfortable with voicing their opinions in class and felt that those opinions were received positively. Neither group felt that an equal gender representation in the course was needed to improve their willingness to speak in class. Both female and male students were equally comfortable asking female lecturers/tutors for help. While male students were just as comfortable seeking help from male lecturers/tutors, female students were significantly less keen on asking male staff for help (MannWhitney test, $\mathrm{p}=0.031$ ). Female role models were regarded more important by female students, but not significantly so. A summary of results is presented in Table 7.

\section{Table 7: Agreement with gender related aspects of the course (as percentage of students)}

(4,5 - agree, strongly agree; 1,2 - strongly disagree, disagree)

\begin{tabular}{|l|c|c|c|c|}
\cline { 2 - 5 } \multicolumn{1}{c|}{} & \multicolumn{2}{c|}{ Females } & \multicolumn{2}{c|}{ Males } \\
\hline Aspect of the course & $\mathbf{( 4 , 5 )}$ & $\mathbf{( 1 , 2 )}$ & $\mathbf{( 4 , 5 )}$ & $\mathbf{( 1 , 2 )}$ \\
\hline $\begin{array}{l}\text { There are no problems with having more male than } \\
\text { female students in the course. }\end{array}$ & 59 & 17 & 51 & 28 \\
\hline Male students "hog" computers in laboratories. & 18 & 43 & 14 & 59 \\
\hline $\begin{array}{l}\text { The content of the course includes examples, exer- } \\
\text { cises, and assignments that are male oriented. }\end{array}$ & 9 & 50 & 10 & 57 \\
\hline I find the programming subjects difficult. & 42 & 22 & 35 & 30 \\
\hline I am comfortable voicing my opinions in class. & 32 & 21 & 41 & 24 \\
\hline I prefer to work with female students. & 24 & 31 & 36 & 15 \\
\hline I prefer to work with male students. & 7 & 50 & 22 & 17 \\
\hline $\begin{array}{l}\text { I would be more comfortable voicing my opinions, if } \\
\text { there were equal numbers of male and female stu- } \\
\text { dents in class. }\end{array}$ & 11 & 53 & 14 & 48 \\
\hline $\begin{array}{l}\text { Opinions or ideas that I voice in class are received } \\
\text { positively. }\end{array}$ & 32 & 5 & 37 & 9 \\
\hline $\begin{array}{l}\text { I feel comfortable asking female lecturers/tutors for } \\
\text { help. }\end{array}$ & 57 & 14 & 59 & 13 \\
\hline $\begin{array}{l}\text { I feel comfortable asking male lecturers/tutors for } \\
\text { help. }\end{array}$ & 43 & 21 & 54 & 11 \\
\hline I prefer to be taught by female lecturers/tutors. & 13 & 31 & 22 & 18 \\
\hline I prefer to be taught by male lecturers/tutors. & 2 & 40 & 19 & 19 \\
\hline $\begin{array}{l}\text { It is important for female students to have female } \\
\text { role models in the course. }\end{array}$ & 33 & 22 & 23 & 24 \\
\hline
\end{tabular}


The last question in the survey sought information about preferred source of help with respect to academic and personal problems. For females, the most preferred source of academic help was their fellow female students followed closely by female lecturers; male tutors came last. For males, the results 'gender-reversed' but otherwise identical, that is fellow male students were the first choice, followed by male lecturers with female tutors in the last position.

When seeking help on personal problems, female students would again firstly turn to their fellow female students. The next three choices of female lecturer, female tutor and fellow male student were far behind the first choice; male tutor was the least preferred option. Male students, too, nominated their fellow male students as, by far, the most preferred source of help on personal problems. Their next three preferences were fellow female student, male lecturer and female lecturer; female tutor was the least preferred choice.

\section{Summary}

The fact that over one third of female students entered the computing course after completing further postsecondary training, may suggest that this type of training is a good preparation for computer science for females. Conversely, significantly more males than females came to the course straight after high school. This may be a vital clue to the problem of under-representation of females in the computing course. It may suggest that the course either does not appeal to high school females, or that the information about the course does not reach them in the first place. The importance of location (of the course and campus) may correspond to the cultural and linguistic profile of the student population in the course. Its particular importance to female students may be associated with safety issues, travel time, and the juggling of family commitments.

The first year, particularly the first semester, of the course emerged as the 'make or break' period especially for female students. Not only was it an important period with respect to adjustment to the course but also it was a period most likely to influence most female students' decisions about quitting the course. It appears that staff encouragement mattered little in dissuading female students from quitting, but the support of fellow students was important. Male students highlighted family encouragement to continue with the course significantly more often than females did. Is this a sign of gender bias within the family?

While the lack of female role models in the course was not identified as important, the preference for seeking help from female as opposed to male staff members seems to suggest to the contrary. Is it gender stereotyping or are female staff members more available to help?

\section{Conclusions}

This paper reports on the findings of a study exploring the relationship between gender bias in computing courses and attrition rates of female students from these courses. Since gender characteristics, such as role stereotyping, mathematical ability, interest and attitudes towards computers were not sufficient to explain the increasing loss of females from computing, it appeared that characteristics related to the ICT environment might exaggerate gender differences. Hence, this study was directed at environmental conditions within the control of the University including course curriculum, pedagogical techniques, access to computers in the classroom, class participation, and institutional support.

The initial findings of the study obtained from focus groups with students yielded some unexpected results. The responses of the students were surprising in terms of their overall assessment of the computer science course, especially against the background of diminishing female numbers. Although occasional standard responses with respect to computing and predominantly male classrooms were evident, the overwhelming message delivered by all students, male and female alike, was that there were no major gender-related problems in their learning environment. This 
applied to the logistical arrangements, academic staff, pedagogical methods, and course content. Nonetheless, female students reported uneasiness pertaining to their desire to have closer interactions with their female peers and their overall concern with the high attrition rates. This concern was expressed in terms of a need for increased support for female students, especially in the early days of their involvement with the course.

The results of a subsequent survey confirmed several of the focus groups findings: the lack of gender balance in the course was considered immaterial, as was the gender of the lecturers and tutors; the course curriculum was deemed gender neutral; and, overall difficulty of the course and overall satisfaction with the course were rated similarly by both male and female students. However, some of the survey results contradicted the findings of the focus groups, notably the equal access to computers in laboratories, and problem free group-work. Moreover, although female students did not regard the under-representation of females in the course as a problem, they singled out their fellow female students as the vital source of both academic and personal help, thereby reiterating the need for female peers in the course.

Transition to the course was identified as a possible factor contributing to high attrition rates of females in computing courses. Not only did the female students take considerably longer to settle into the course, but they also were most likely to drop out of the course after the first year of study. The large number of students contemplating dropping out of the course is a concern, as is the largely insignificant role of staff in persuading those students to stay.

While this study has provided some explanation of the high attrition of females in computing courses, the challenge still remains to develop strategies to arrest it or, better still, reverse the trend.

\section{References}

Blank, D., \& Kumar, D. (2002). Patterns of curriculum design. In Proceedings of the IFTP WG3.2 Conference on Informatics, Curricula, Teaching Methods and Best Practice (pp.77-86). Boston: Kluwer Academic Publishers.

Camp, T. (1997). The incredible shrinking pipeline. Communications of the ACM, 40(10), 103-110.

Cohoon, J.M. (2001). Toward improving female retention in the Computer Science major. Communications of the ACM, 44(5), 108-114.

Cohoon, J.M. (2002). Recruiting and retaining women in undergraduate computing majors. SIGCSE Bulletin, 34(2), 48-52.

Clayton, D., \& Lynch, T. (2002). Ten years of strategies to increase participation of women in computing programs, The Central University experience: 1999 - 2001. SIGCSE Bulletin, 32(2), 89-93.

Crombie, G., Abarbanel, T., \& Anderson, C. (2001). Getting girls into tech classes. The Education Digest, 66(5), $42-48$.

Crump, B.J. (2001). Equity in the tertiary programming learning environment. In Proceedings of the Australian Association for Research in Education Conference (AARE 2001). Fremantle, Australia. Retrieved July 2003, from http://www.aare.edu.au/01 pap/cru01022.htm

Davies, A.R., Klawe, M., Ng, M., Nyhus, C., \& Sullivan, H. (2000). Gender issues in computer science education. In Proceedings of the National Institute of Science Education Forum, Detroit. Retrieved: July 2003, from http://www.wcer.wisc.edu/nise/News_Activities/Forums/Klawepaper.htm

DEST (Department of Education, Science and Training) (2004). Higher education attrition rates 19942002: a brief overview. Research note no. 1. Retrieved August 2005, from http://www.dest.gov.au/NR/rdonlyres/8A245011-4F59-4D99-9D97-A1AD89D0C669/1043/1.pdf 
DEST (Department of Education Science and Training) (2005). Student outcome indicators for the Learning and Teaching Performance Fund: Technical note no.2. Retrieved August 2005, from http://www.dest.gov.au/sectors/higher education/policy issues reviews/key issues/assuring quality i n higher_education/technical_note 2. htm

Fisher, J. (2003). Are we really serious about having women in IT? Information Age, June, 2003. Retrieved July 2003, from www.acs.org.au/infoage.html

Gilbert, J. (2001). Science and its 'other': Looking beneath 'woman' and 'science' for new directions in research on gender and science education. Gender and Education, 13(3), 291-305.

Haliburton, W., Thweatt, M., \& Wahl, N.J. (1998). Gender differences in personality components of Computer Science students: A test of Hollands' congruence hypothesis. ACM SIGCSE Bulletin, 30(1), 7781.

Henwood, F., \& Miller, K. (2001). Boxed in or coming out? On the treatment of science, technology and gender in educational research. Gender and Education, 13(3), 237-242.

Lazowska, E. (2002). Pale and Male: $19^{\text {th }}$ Century design in a $21^{\text {st }}$ Century world. Inroads - SIGSE Bulletin, Women in Computing, 34(2), 11-12.

Levenson, N. (1999). Educational pipeline issues for women. CRA Snowbird Conference Panel Presentation. Retrieved July 2003, from http://www.ai.mit.edu/people/ellens/Gender/pipeline.html

Margolis, J., Fisher, A., \& Miller, F. (1998). Geek mythology. Women in Computer Sciences: Closing the gender gap in higher education. Retrieved July 2003, from http://www.cs.cmu.edu/ gendergap/working.html

Margolis, J., Fisher,A., \& Miller, F. (1999). Caring about connections: Gender and computing. IEEE Technology and Society Magazine, Winter, 13-20.

Miliszewska, I., \& Horwood, J. (2000). Women in Computer Science: Experiences from Victoria University. In Proceedings of Seventh International Conference on Women, Work and Computerization (pp.50-57). Boston: Kluwer Academic.

Miliszewska, I., \& Horwood, J. (2002). Acknowledging girlpower: Reconceptualisation of women in computing. In Proceedings of the $12^{\text {th }}$ International Conference of Women Engineers and Scientists, Paper no. 66, Ottawa, Canada.

Newmarch, E., Taylor-Steele, S, \& Cumston, A. (2000). Women in IT - What are the barriers? In Proceedings of the Network of Women in Further Education Conference (pp.86-91). Canberra, Australia: Department of Education, Training and Youth Affairs.

Nielsen, S.H., von Hellens, L.A., \& Wong, S. (2001). The male IT domain: You've got to be in it to win IT. In Proceedings of the $12^{\text {th }}$ Australasian Conference on Information Systems (ACIS 2001) (pp.1-12), Coffs Harbour, Australia.

Rees, T. (2001). Mainstreaming gender equality in science in the European Union: the 'ETAN' report. Gender and Education, 13(3), 243-260.

Scragg, G., \& Smith, J. (1998). A study of barriers to women in undergraduate Computer Science. In Proceedings of the $29^{\text {th }}$ SIGCSE Technical Symposium on Computer Science Education (pp.82-86), Atlanta, GA.

Springer, L., Stanne, M.L., \& Donovan, S. (1999). Effects of small-group learning on undergraduates in science, mathematics, engineering and technology: A meta-analysis. Review of Educational Research, 69(1), 21-51.

Teague, J. (2002). Women in computing: What brings them to it, what keeps them in it?' SIGCSE Bulletin, $34(2), 147-158$.

Weinman, J., \& Haag, P. (1999). Gender equity in cyberspace. Educational Leadership, 56(5), 44-49. 
Zeldin, A., \& Pajares, F. (2000). Against the odds: Self-efficacy beliefs of women in mathematical, scientific, and technological careers. American Educational Research Journal, 37(1), 215-246.

\section{Biographies}

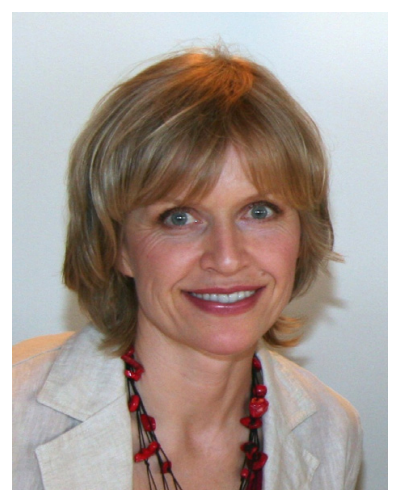

Iwona Miliszewska is a senior lecturer in computer science at Victoria University. She has participated in research projects involving transnational education, effective teaching methods, lifelong learning and women in computer science, and has published in these areas. In 2003 Iwona led a research project investigating the relationship between gender bias in computing courses and attrition rates of female students from these courses.

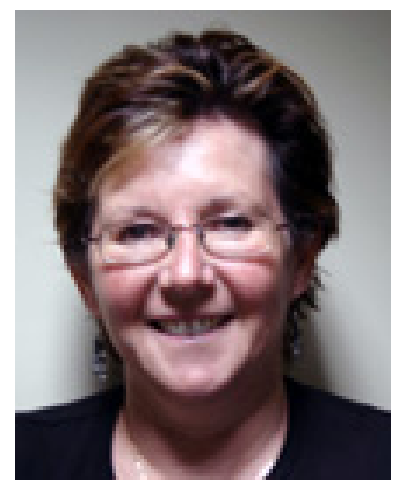

Gayle Barker is a lecturer in the Faculty of Arts, Education and $\mathrm{Hu}-$ man Development at Victoria University. She teaches and has participated in the development and co-ordination of written and oral communication subjects available to undergraduate students in the School of Computer Science and Mathematics. Having worked in these areas, Gayle has developed a particular interest in the integration of females into male oriented courses and professions.

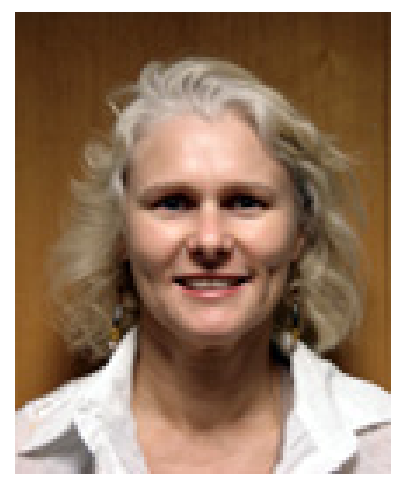

Fiona Henderson has worked as a Language and Academic Skills lecturer with Victoria University for more than 10 years. In that time she has taught a range of students including those in the School of Computer Science and Mathematics. The gender imbalance in that School and the increase in international students both on and offshore have led to Fiona's interest in re-examining teaching practices and approaches and how these can best be met in an economically strained environment.

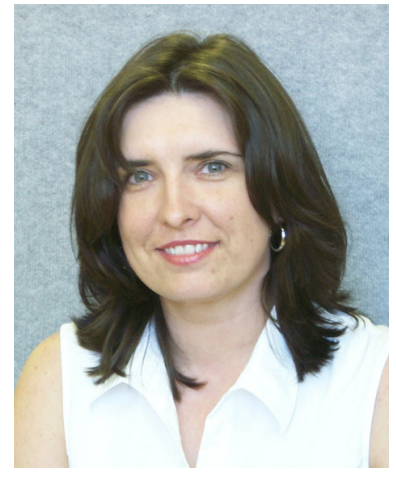

Ewa Sztendur completed her PhD in Statistics at Victoria University in 2005. She has been involved in the teaching of statistics, biostatistics, and statistical consulting since 1998. Ewa's research has made an important contribution to the theory and practice of Response Surface Methodology. 